\title{
Rhetorical Texts of the 4th Century A.D. about Wealth and Its Loss
}

\author{
N. Tsitsanoudis-Mallidis ${ }^{1, *}$, Ch. Stergioulis ${ }^{2, *}$ \\ ${ }^{1}$ Assistant Professor of Linguistics and Greek Language, Department of Preschool Education, University of Ioannina \\ ${ }^{2}$ Doctor of Byzantine Literature, Aristotle University of Thessaloniki \\ *Corresponding author: nitsi@cc.uoi.gr; babisterg@yahoo.gr
}

Received June 12, 2014; Revised October 12, 2014; Accepted October 27, 2014

\begin{abstract}
With this announcement we will try to present to the most possible extent, how wealth and its loss is dealt with by Basil of Caesarea and John Chrysostom, but also the way in which man is forced to deal with problems arising from both acquisition and possession and also loss-always according to the eternal word of the Gospel and of

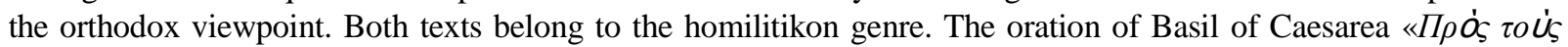

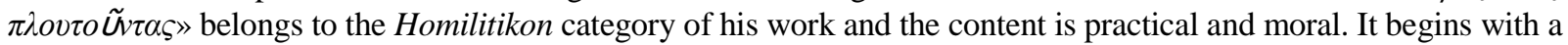
very short prologue (exordium). From the first lines of oration he makes sure he illustrates a portrait of the rich

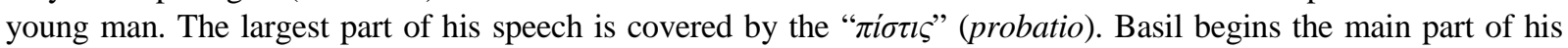
oration justifying the formulation of his view in the preamble of the rich young man. Getting to the main point of the Cappadocian bishop, he brings forward the following reasonable question to the rich young man and indirectly to his audience: "If you have guarded from your youth the command of love and attributed to the poor as much as you have offered to yourself, then how have you accumulated this very large fortune?" In the following section of his oration he makes sure to go to a new question: "But how are you going to exploit wealth?" Man should manage his wealth in the way that the Lord commands. Then wealth remains to the ownership of the person who possesses it, though when man tries to save it, its lost. Basil even castigates the habit of the avaricious wealthy to bury and save their precious possessions in vaults, bringing up the excuse that the future is uncertain. In the next section of his oration Basil the Great goes over to the question: «And how will we live without precious possessions?" The confrontation of wealth is a trial of whether we want a true life or a temporary enjoyment. Special emphasis is given to how to deal with the situation, when the woman is involved. If the woman too loves wealth, the disease is even greater, this would motivate a man to a number of pleasures. The ecclesiastical man also castigates with harshness the greediness of the rich. The desire to acquire more and more possessions creates a dependency relation of them. And indeed man feels poverty, since he constantly has the need of acquiring more. The following section of the

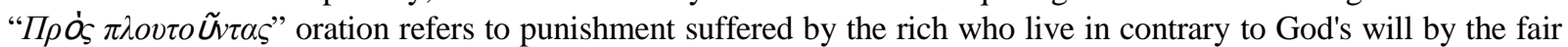
Judge. An issue that also employs Basil of Caesarea is the "nature of wealth". Wealth should not be a gallows for souls nor a hook of death. Basil the Great even catches up before any objections are made, that the acquisition of wealth is necessary for the future of children. Finally, before passing in to the epilogue of his oration refutes to the arguments of those who are childless and plead the excuse that they do not offer part of their wealth to the poor, "because of their needs." The epilogue small in length is designed to motivate the listener to abandon the futile attempt to acquire wealth and help him to prepare as best as possible for the kingdom of Heaven. In the same direction with the archbishop of Caesarea concerning the proper management of wealth John Chrysostom also

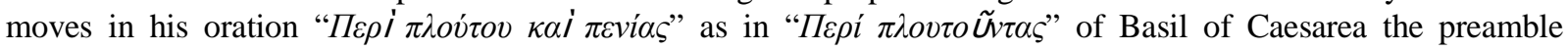
(exordium) is short. In the occasion of the comparison of the rich man and Lazarus Chrysostom criticizes those who resent God, because they themselves are not wealthy and do not imitate the poor Lazarus. Chrysostom passes over to the main part of his oration through a rhetorical question: "Why do you think being wealthy is so important?" And the reasons why man hunts wealth are: pleasure, flattery, fear and vengeance. So wealth according to Chrysostom is an ungrateful slave sadistic and 'androfonos', who is ready to be paid to lead his master to slaughter. After referring to the example of Eutropius, Chrysostom will pass to a new section of his oration: wealth betrays those who do not use it correctly. He also finds it appropriate to deal with the issue of equality between human beings: rich and poor are equal and do not differ in anything. Thus believers must cease to envy the rich and become imitators of the Apostles, the Prophets and of Christ Himself. He fails to understand the behavior of people who prefer the small instead of the large, once they fall in the trap of the devil. Therefore, wealth, according to Chrysostom is not a "great possession" great possession is the acquisition of fear of God. The last section begins with a question: "Isn't it a nonsense not to know what is beneficial for you?" There is no, more brainless man from the slave of money. God gave wealth, not to lead man to destruction, but to use them in pleasing to God works and in this way to be saved. Finally, in the epilogue, Chrysostom advises believers to face with Christian manner possible loss of their property and to bear in mind the example of "fair Jov". Both great Fathers as the only way to deal with avarice and as for the
\end{abstract}


only means of getting out of it, propose the adoption of an ascetic morality in the accordance of a Christian model: self-control and self-sufficiency in daily life. Besides the moral problem of ascetic it is consisted in man's relationship with material possessions and not their management, as appropriately pointed out in the two inspiring orations.

\section{Keywords: christian rhetoric, discourse analysis, metaphor, talkative type}

Cite This Article: N. Tsitsanoudis-Mallidis, and Ch. Stergioulis, "Rhetorical Texts of the 4th Century A.D. about Wealth and Its Loss.” American Journal of Educational Research, vol. 2, no. 10 (2014): 955-962. doi: 10.12691/education-2-10-16.

\section{Introduction}

The most important figures the Christian rhetoric, theology and philosophy in the 4th century have to show, are the Cappadocian Fathers, Basil of Caesarea (the Great), Gregory of Nazianzus dubbed Theologian, Gregory of Nyssa, and the native of Antioch John Chrysostom. All four of them emerged as excellent orators and contributed greatly to the shaping of classical rhetoric through Christianity using creatively the Ideas of Hermogenes ${ }^{1}$. The Cappadocian Fathers also gave new life to the flamboyant writing rhetoric of eulogistic speeches, mostly about the martyrs of Christian faith or saints who excelled in the virtuous life.

In this paper we will attempt to present, as thoroughly as possible, not only how wealth and its loss is treated by Basil of Caesarea and John Chrysostom, but also the way in which man is forced, according to them, to deal with problems arising from both acquisition and possession of and by the loss of wealth-always according to the eternal word of the Gospel and the Orthodox point of view. Despite the fact, however that Basil and John Chrysostom were very capable orators, a rhetorical approach to the texts was necessary, to reveal the contribution of the rhetoric art in the best comprehension of meanings.

Basil of Caesarea (330-379) ${ }^{2}$ was the scion of a wealthy family, which influenced his spiritual path. He learned his first letters close to his father, who was already working as a teacher of rhetoric in Neokaesaria of Pontus, while he was greatly influenced, as far as his religious education was concerned, by his grandmother Macrina. He continued his studies in neighboring Caesarea (a prosperous, at that time, urban center of Asia Minor),

\footnotetext{
${ }^{1}$. One of the most important educators and orators of the Roman Empire (app. 160-230 AD) from Tarsus of Cilicia. Regarding Hermogenes, see: Hermogenis, Opera, ed. H. Rabe, Rhetores Graeci, VI, Teubner,

Stuttgart 1969. George Kennedy, History of Classic Rhetoric, Ancient Greek and Roman, translation by Nikos Nikoloudis, supervision by Ioannis Anastasiou, Athens 2000, p. 332-346• M. Patillon, Hermogène. L'art rhétorique, Paris 1997· M. Heath, Hermogenes On issues: strategies of argument in later Greek rhetoric, Oxford University Press, 1995 C.W. Wooten, Hermogenes' on types of style, University of North Carolina Press, 1987.

${ }^{2}$. Regarding Basil of Caesarea, see: Clavis Patrorum Graecorum (CPG) cura et studio Mauritii Geerard, I-IV, Brelops-Turnhout 1974, vol. II, 140, 2835-178, 3005 (with references to publications, translations, and bibliography)· Lexicon des Mittelalters, vol. I, pp. 1530-

1532 - Christopher Walter, Biographical Scenes of the three Hierarchs, (Revue des Études Byzantines 36, 1978) pp. 232-234 and 243-250 (with

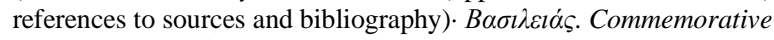
volume for the 1600 years since the passing of (St.) Basil the Great, [H. M. of Thessaloniki], Thessaloniki 1979. Commemorative volume for the 1600 years since the passing of (St.) Basil the Great (379-1979),

[Aristotle University of Thessaloniki, Theological Faculty], Thessaloniki 1981· Religious and Moral Encyclopaedia, vol. 3, pp. 681-696.
}

where he met with Gregory of Nazianzus, Constantinople and completed the famous Faculty of Athens his studies - along with his friend Gregory. Returning to Caesarea he worked briefly as an orator, until his complete dedication to the Church and his ascent to the episcopal throne of the city (370). His incumbency as a bishop was brief, as he died relatively young (January $1^{\text {st }}, 379$ ).

Basil of Caesarea ${ }^{3}$ was a prolific writer. His work, according to Detorakis, "had a tremendous impact on the formation of ecclesiastical literature throughout the Christian world” (Detorakis, 1995). An important part of his writing activity consists of lectures and speeches.

A contemporary of Basil of Caesarea was John Chrysostom (344/354-407) ${ }^{4}$. He was born in Antioch in a prominent family. His father, Sekundos, was a senior army officer. In his hometown he attended philosophy courses hear Andragathius and, according to the historian Socrates, he also attended rhetoric courses in the school of Libanius (Koukoura, 2003) ${ }^{5}$. He was an excellent orator, but he chose to devote himself to the Church, rejecting his involvement with the legal profession and one, it seems, brilliant career. He was ordained as a priest in Antioch in 386 by the Bishop of the city, Flavianus. Soon enough, his reputation as a competent and motivated priest spread and for this reason he was elected archbishop of Constantinople on February $26^{\text {th }}$, 398. As Archbishop, John Chrysostom was often critical of the luxurious life of lords and clergy. Thus, he got enemies in the upper layers of Byzantine society, who were seeking ways to get rid of his annoying presence. His persecution was led by the empress Eudoxia, who, with Patriarch Theophilus of Alexandria (385-412) as an accomplice, succeeded in getting Chrysostom's conviction and his exile, first in Koukousos of Cappadocia and, with a later imperial decree, in Pityous of Pontus. John Chrysostom, though, never arrived at this latter place of exile, as he died during

\footnotetext{
${ }^{3}$. From the main works of Basil of Caesarea is: S. Giet, Homélies sur l' Hexaémeron, [Sources Chrétiennes 26], Paris 1929· B. Pruche, Basile de Césarée, Traité du Saint-Esprit, [Sources Chrétiennes 17 bis], Paris 1968· Y. Courtonne, Saint Basil Lettres I-III, Paris 1957-1966· F. Boulenger, Saint Basile, Aux jeunes gens, Paris $1965^{2} \cdot$ N. Wilson, On Greek Literature, London 1975. U. Neri, Basilio di Cesarea, Opere ascetiche, Torino 1980 - W.-D. Hauschild, Basilius von Caesarea, Briefe, Stuttgart 1990 Fr. Xaver Risch, Pseudo-Basilius Adversus Eunomium, $I V-V$. Einleitung, Übersetzung und Kommentar, Leiden 1992 [= Vigiliae Christianae Supplements 16].

${ }^{4}$. For John Chrysostom, see: CPG II, 491, 4305-4672, 5197· Lexicon des Mittelalters, V, pp. 563-564 The Holy Chrysostom. Proceedings of the $16^{\text {th }}$ Theological Conference [Holy Metropolis of Thessaloniki], Thessaloniki 1996

${ }^{5}$. Socratis Scholastikos, Ecclesiastic History, ed. Robert Hussey, Socrates Sholasticus Ecclesiastica Historia, I-II, Oxonii 1992 CPG 6028. [PG 67, 29-842], Book VI, Chapter C, 660 [665]. About the possible attendance by Chrysostom at the rhetoric school of Libanius, see Festugiére, Antioche, pp. 409-410.
} 
on the way, in Comana of Pontus, crummy from exhaustion and hardships.

The writing of Chrysostom impresses not only with of its magnitude, but also with its theological and stylistic completeness. The bulk of his writing activity consists of the speeches he gave at all times, without any prior special preparation on his part. A dominant position in the sermon of Chrysostom is held by the term proairesis (Bozinis, 2003), a term known to his wide audience and pronounced in earlier patristic tradition. Thus, Chrysostom soon developed into a leading ecclesiastical figure of his time and the fame of his name reached every corner of the empire. The greatest service, however, offered by Chrysostom to the ecclesiastical rhetoric is that he, more than anyone else, "upgraded preaching, a simple speech developing a biblical text, at the level of high rhetoric art" (Kennedy $1983 \cdot$ Kennedy, 2000).

Both texts belong to the talkative type. In this kind of text, the topic "comes from the biblical passage and its order shall be determined by the same biblical text analysed” (Koukoura, 2003).

\section{The homilia of Basil of Caesarea "Пpò $\varsigma$

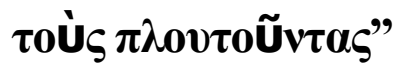

The homilia of Basil of Caesarea " $\Pi \rho \dot{\rho} \varsigma$ $\tau o \dot{U} \varsigma$ $\pi \lambda o v \tau o \tilde{v} \tau \alpha \varsigma^{\prime 6}$ falls into the category of his work called Omilitika; its content is practical and moral (Detorakis, 1995). It begins with a short prologue (Lausberg, 1998. Pratsch, 2005. Høgel, 2002. Lieberich, 1900 Hunger, 1964 · Browning, 1966 · Mazal, 1974)exordium (39, I, 1-14) since the topic has already been mentioned, as he points out, in a previous speech of his: "We have mentioned before this young man" (39, I, 1) and therefore there is no reason, to remind diligent" listeners" the previously mentioned. Thus, he managed to attract, from the first few lines of his speech, the prosexis and the eunoia of the audience. The third objective of the preamble, the readiness in learning, is also achieved, as Basil of Caesarea makes it clear to the listeners that he will talk about the rich young man of the Gospel of Matthew (19, 16-26) and not the law abiding one mentioned in the gospel of Luke (10, 25-37).

From the very first lines of his homilia, Basil of Caesarea makes sure to outline the character of the rich young man: "he seemed to us that he had mixed morals" (39, I, 9), as the young man addressed questions to Jesus, being in a healthy disposition, but he was not ready, neither to obey, nor to apply what Jesus suggested. So, the rich young man is, according to Basil, not only praiseworthy, but also "most villainous", as well as “desperate”.

An important part of his word is dedicated to pistisprobatio (Theodorakopoulos, 1989). Basil of Caesarea starts the main part of his speech justifying his view about the young rich man that was expressed in the preamble. He particularly, though, stresses the fact that the young man should sometimes be scolded the rich young man thinks and acts like most men, as his intention "did not aim at something truly good, but at somethink favored by

\footnotetext{
${ }^{6}$. The edition: P. G. 31, 277-304 · Yves Courtonne, Saint Basile Homélies sur la richesse: édition critique et exégétique, Paris 1935, p. 45-47· CPG, II, 2851.
}

the many” (39, I, 16-17). This is why he (the young man) exited sad after his meeting with Jesus, dominated by the "lust for riches" (39, I, 20). It was just the time for Basil of Caesarea to use the second person singular (Stergioulis, 2010), also using the "pysmatiko schima" (use of rhetorical questions) [Efstathiou, 1994- Abrams, 2005-Stergioulis, 2010], to address, not only the aforementioned young man of the Gospel, but also the contemporary listeners and subsequent readers of his word, skewering the "lust for riches". Typical is the last of the questions with which Basil condemns the behavior of the young man who, if suffering from any physical illness or had a defect in nature, would refuse the treatment that was recommended by the physician? Why then is he denying the salvation of his soul offered by the "great physician of souls" $(41, \mathrm{I}, 14)$ ? The use of rhetorical questions helps the arguments St. Basil makes and stimulates feelings of repulsion towards the rich young man. So, the orator naturally reaches a first conclusion, addressing the young man and, simultaneously, each one of us: "you have falsely proclaimed that you love your neighbor as yourself” (41, I, 17).

Entering the very essense of the subject, the Cappadocian bishop lays out the following reasonable question, first to the rich young man and, indirectly, to the audience: "If since the time of your youth you were cherishing the command of love and gave the poor as much, as you gave yourself, then how come you have accumulated this very large fortune?” (41, I, 19-21). And the answer is equally impressive: "The more riches you have, the more you lack love” (41, I, 27-28). The lack of love, thus, is the cause for the accumulation of wealth, because, if he had loved his neighbor, he would have thought to get rid of the money long ago. By using an unbound (Courtonne, 1935 - Efstathiou, 1994- Lausberg, 1998. Sakellariadis, 2004 Pernot, 2005· Stergioulis 2010) structure and, with a series of hypothetical syllogisms (enthymymata) [Theodorakopoulos, 1989] ${ }^{7}$ St. Basil suggests the right way of life and action: Nobody would be sorry about the money, if he/ she cared to provide clothes to the naked, food to the hungry, to open the door of his/ her home to every/ any stranger, to take care of orphans. In this case it makes no sense for him/ her to be sorry, since he/ she will be offering "gold, silver and estates; that is, stones and soil/ dirt" (43, I, 10), in exchange for eternal life. So, St. Basil defines very precisely the term love, which, "according to Apostle Paul, is the supreme virtue of man, has to do with God and each man's neighbor, and is characterized by selflessness and lack any trace of selfishness” (Pelegrinis, 2009, p. 20).

With full knowledge of the rules of the art of rhetoric, according to which the rhetorician must prepare the listener for the transition from one section to another (Russel, 1981), he moves to the next section of his word, posing a new question: "But, how is the wealth useful?" (43, II, 12-13). According to St. Basil and the Cynical point of view, wealth is of no use; it doesn't satisfy the need for clothing, since a single garment-"tunic" is enough (43, II, 13)-neither the need for food, since a single loaf of "bread" can "fill the stomach" (43, II, 15); it doesn't bring glory, since the true glory lies in the

\footnotetext{
7. The enthymymata are rhetorical, usually short reasonings based "'on common understanding and present relevant issues to be judged by human experience" (Theodorakopoulos, Introduction to the Attic Oratory, p. 112).
} 
Kingdom of Heaven. Instead, a person must manage his/ her wealth in the way the Lord commands. Then, the wealth stays with the person who owns it, while, if he/she tries to safeguard it, it is lost: "If you safeguard it, you won't have it - If you share it, you won't lose it” (45, II, 56) [Courtonne, 1935. Smyth, 1984 · Efstathiou, 1994 Lausberg, 1998. Stergioulis, 2010] ${ }^{8}$.To forestall possible objections by his listeners, he even stresses that the devil is the one who motivates the rich to indulge in various useless expenses, and so they (the rich ones) get used to saying that they seek to take care of the present and the future, both their own and their children's, accumulating wealth, but then they waste it on unnecessary expenses, which they consider to be necessary. It is the right time for the orator to give examples ${ }^{9}$ of this kind of thinking and lifestyle of the rich: the need for a residence is not only satisfied, but they also see to that there is luxury: vehicles do not serve the need for movement and better service, but rich men use one vehicle to move and a different one to work they spend too much money on their horses, grooming them "as if they were bridegrooms" (45, II, 27).

St. Basil immensely criticizes, the habit of stingy rich people, to store their riches deep in the ground or in vaults, using the excuse that the future is uncertain and that "we may encounter some unexpected needs” (47, III, 16). By using logical arguments, he is trying to quash the aforementioned view: a) after failing to spend their fortune, in order to satisfy foolish desires, they are trying to hide it in the ground that is, they are burying their gold deep in the ground, having previously dug the ground, in order to find gold and b) while burying their gold into the ground, they are also burying their hearts. Also using a gospel passage: "Where your treasure lies, there also lies your heart” (47, III, 22-49, III, 1$)^{10}$, as well as a paromoiosis (Spengel, 1856· Lausberg, 1998· Sakellariadis, 2004 Abrams, 2005. Stergioulis, 2010) ${ }^{11}$ (the image of a wayfarer, who, due to his laziness, does not enter the city after a strenuous route, but prefers to sleep in a hotel out of it, depriving himself of the possibility to wander around, 49, III, 3-7), the orator penetrates the soul of the stingy ones, who refuse to get rid of their belongings. The result: "You shall not be admitted in the Kingdom of Heaven" (49, III, 12).

St. Basil moves to the next section of his speech, with a question · a question that could be expressed by the listener after what has been said so far by the orator: "And how are we supposed to live, if we ger rid of everything we have acquired? What kind of life will that be, if we sell everything we got?” (49, III, 5-17). The answer the Cappadocian Father gives is simple, concise and unambiguous: "Do not question what the Lord commands" (49, III, 17). Dealing with the issue of wealth, after all, is nothing more, than merely a test of whether we want a true life or a temporary enjoyment. Those thinking wisely will use the wealth according to the divine commandments and not, in order to enjoy material goods.

\footnotetext{
${ }^{8}$. To give special emphasis to the specific part, (St.) Basil uses a specialized rhetoric format, which is characterized by complete harmony, called "pariso", “isokolon”, “omiotelefton”.

${ }^{9}$. The examples "must be used by the orator, in case he does not have enthymymata, or entymymata boosters, as they seem like the depositions by witness that further support the evidence" (Theodorakopoulos, Introduction to the Attic Oratory, p. 113).

${ }^{10}$. Gospel of Matthew, 16, 21.

${ }^{11}$. When the paromoiosis is present as an image, it gives clarity to the word of the orator.
}

So, when they get separated from their riches, they are rejoicing, as if they were relieved from the acquisition of alien stuff; they do not grieve, as if they had lost their own'. Cognizant of the problems of his flock, the great Father also reminds his audience of the responsibilities to be undertaken before the Great Judge, the Lord: "What are you going to tell the Lord, when you dress your walls with thick carpets, but you don’t put clothes on a man?” (51, IV, 3-4).

Special emphasis is given to the way of dealing with things, when a woman is involved. If the woman also loves wealth, the disease is double because she will urge her husband to enjoy a multitude of pleasures. The use of a saying is essential for the orator, at this point of his homilia: "No amount of wealth is enough to satisfy a woman's desires; not even if it flowed like the water of a river (that is, never running out)" (51, IV, 15-17). How, then, will a man take care of his soul, when he is serving female desires? Thus, evil moods and desires of such a woman stifle the will-weak husband, like tempests and storms sink ships that are flawed. When a couple is dealing with the futile, they have no time to deal with the problems of others and resent the implementation of the Lord's mandate to "sell your possessions and give to the poor, so that you will be equipped for the eternal pleasure (of Heaven)" (53, IV, 1-3).

This holy man is also vehemently critical of the rich men's greed. A man's desire to acquire more and more goods makes him completely dependent on them, feeling really poor, as he constantly feels the need to acquire more. So the greedy rich man is like the drunkard, for whom the addition of more wine, is a chance for him to drink even more (a paromoiosis that reminds us of the Homeric ones) [Spengel, 1856. Stergioulis, 2010] ${ }^{12}$. Thus, his mental health is destroyed, since he is most interested in accumulating more wealth he is not pleased with the goods already acquired and the fact that he is richer by many, but he is sorry, that there maybe some men, one or two, richer than him ${ }^{13}$. In order for this argument to reach deep inside the souls of audience, (St.) Basil likens the rich men: a) to those who climb a ladder and do not stop until they reach its very last step of [accordingly, rich people are not released from their passion, until they have reached so high a point, that their fall is certain $(55, \mathrm{~V}, 16$ 20)] and b) to the rivers that initially are small, but with the addition of affluents, they become larger, they flood and by the severity of their current, they drift anything found in their path (57, V, 16-22). Because "the greedy one desires evrything his eyes can see” $(57, \mathrm{~V}, 1)$. And to place more emphasis on this view, St. Basil invokes several scriptural passages (Ecclesiastes ${ }^{14}$, Isaiah ${ }^{15}$ ),

\footnotetext{
12. The paromoiosis was presented in the form of a parabole which gives vitality to the speech/word.

${ }^{13}$. Similar is the view of Xenophon, expressed in his work "Ieron" (4,

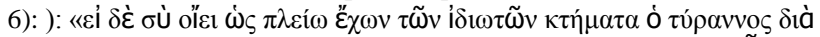

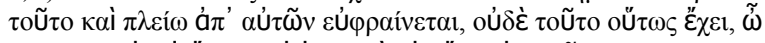

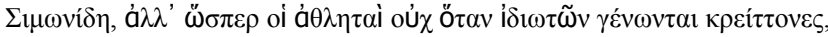

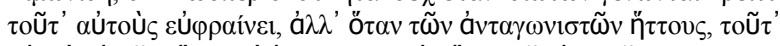

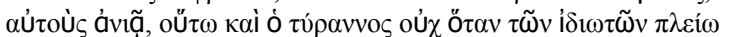

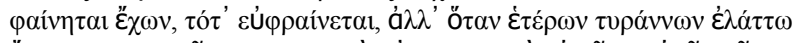

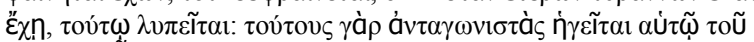

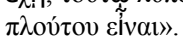

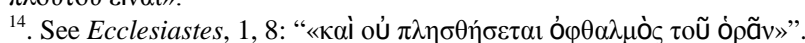

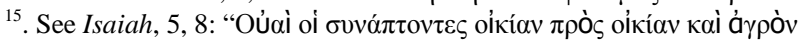

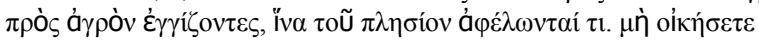

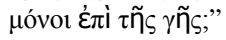


examples from the Old Testament (the murder of Naboth ${ }^{16}$ ) compares the rich man to the sea, the night and the violence of fire, which "always seizes, always grabs" (57, $\mathrm{V}, 16)$.

Faced with the threat of the rich man and the oppressive power exercised upon the weak and poor, according to St. Basil, everyone succumbs and shrivels out of fear. The weak people care only not to suffer worse and refuse to seek satisfaction for the hardships suffered by his tyrannical power.

The next section of St. Basil's homilia, "To the rich ones", discusses the punishment suffered by the rich, who live contrary to God's commands, by the fair judge, the Lord. The reference to the crisis is an important argument, in an attempt of the priest to persuade us, to make a change in our lifestyle. He is addressing each and everyone directly (use of the second person singular, incentive imperative, gospel passages), worrying about the fate of the soul after death and the situation it may be found in: "They will remember the glorious presence of Jesus Christ, those who will resurrect- Those who did good, will live after resurrection, whilst those who acted viciously will be judged (after resurrection) ${ }^{17}$ then shame eternal will fall upon the sinners - fire will destroy the opposing ones $^{18,}$ (61, VI, 13-16).

An issue that also concerns St. Basil is the "nature of wealth” (61, VII, 20) [Courtonne, 1935 - Stergioulis, 2010]. Wealth should not be a gallow for souls, a death hook, or a "lure for sin" (63, VII, 12-13), a cause for wars and murders it should not be cause for the world to become full of malefactors, the seas full of pirates and the cities full of sycophants it should not be the "father of lies" (63, VII, 17), the "forgery creator» (63, VII, 17) and the generator of perjury. Instead, wealth should "contribute to living" and be a "relief for the soul" (63, VII, 20-21).

Basil of Caesarea is even forestalling any possible objection, namely that the acquisition of wealth is necessary for the future of children. He even characterizes this excuse as "a seemly cause for greed" (63, VII, 22). The Lord, according to St. Basil, is the One who will protect children, since He brought them to life- otherwise his command to the rich young man would have no meaning: "If you want to be perfect, sell all of your possessions, and give to the poor". After all, no one can be sure that his children would use wealth in the most rational way. And to give more emphasis to his argument, he cites Ecclesiastes (5, 12 and 2, 18). Besides, if kids squander fortune to pleasures and anything that causes sin, then the parents will suffer double punishment. There are lots of cases, where children without fortune from their parents, managed to build a house and meet their needs. Therefore, our only concern should be the salvation of our soul.

Finally, before moving to the epilogue of his homilia, St. Basil refutes the arguments of those who are childless, and promote the following "seemly cause of their stinginess" (65, VIII, 17), that they do not offer part of their wealth to the poor "for the necessities of life" (65, VIII, 18). Such people, according to the Cappadocian

\footnotetext{
${ }^{16}$. For the murder of Naboth by King Achaav, see $3^{\text {rd }}$ Kingdom, 20.

17. See Gospel of John 5, 29.

${ }^{18}$. See To the Hebrews, 10, 27.
}

Father, do not accept the Lord as a teacher, or the Gospel as a regulator of their lives. This is because they consider that it is more prudent than the Lawgiver. St. Basil cannot believe them, even when they say they will bequeath their property after their death, to the poor. Such an act has no meaning. It doesn't show a pious man, since, as he characteristically notes, nobody trades after the end of a fair, nobody is crowned, when arriving at the end of the games, and no one shows his bracery after the end of a war. (67, VIII, 11-13). Also, none of them can be sure how he will feel the time of his death and whether he will have a chance to prepare his will. While, even if the latter takes indeed place, again things will be fluid, since a falsification of the will is possible, with the use of another stamp or by invoking false witnesses.

Therefore, the emerging conclusion is that the only thing achieved is the deception of them themselves on one hand, since they promise to provide the poor with what they no longer possess, and the eternal punishment on the other. And St. Basil concludes the main part of his speech with a rhetorical question that highlights the futility of life of those who accumulate wealth and not using it in projects of benevolence: "What will be the benefit of a luxurious tomb, a luxurious burial and the necessary for the burial expenses?” (71, IX, 4-5).

The epilogue ${ }^{19}$ (71, IX, 6-16) [Lausberg, 1988. Pratsch, 2005 Stergioulis, 2010], small in size, is designed to stimulate in the soul of the listener specific passions: to make him abandon the futile attempt to acquire wealth and help him prepare as best as possible for the other life to use piety as shroud and faithfully follow the commandments of Christ, "for the poor among us" (71, IX, 10-11) and "to give ourselves relief/salvation" (71, IX, 11-12). If we do what He has requested, then we will become heirs "of the eternal life near Jesus Christ” (71, IX, 15). So St. Basil, like the rest of the Holy Fathers of the 4th century, embraces the eschatological perception "that history does not move in circles, as believed by the ancient Greeks, but is directed toward an ultimate purpose, which is none other than the salvation of the soul of man" (Pelegrinis, 2009).

\section{The homilia of John Chrysostom "Of wealth and poverty"}

The lead of archbishop of Caesarea, on the issue of proper management of wealth, is followed by John Chrysostom, in his homilia "Of wealth and poverty" 20. And in this Homilia, as is the case for St. Basil's "To the rich ones", the preamble (exordium-proemium) is short on the occasion of the parable of the rich man and

\footnotetext{
${ }^{19}$ Regarding the function of epilogue (peroratio), Aristotle will note, in

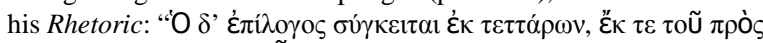

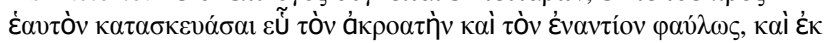

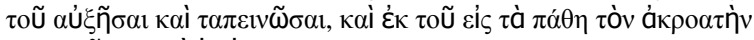

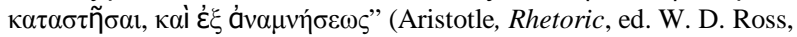
Bibliotheca Oxoniensis, Oxonii 1959, 1419b). Nikolaos Sofistis thinks

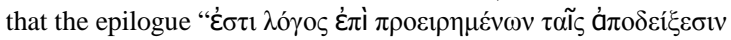

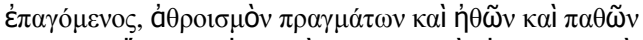

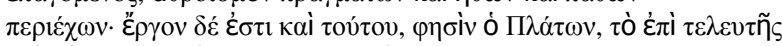

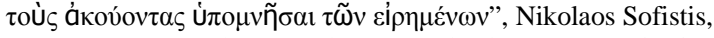
Progymnasmata, ed. Leonardus Spengel, Rhetores Graeci, Lipsiae 1856, III, 350, 32-351, 4.

${ }^{20}$. Regarding the edition of the homilia, see PG 63, 637-645.
} 
Lazarus ${ }^{21}$ Chrysostom criticized those who resent God, because they themselves are not wealthy and do not mimic the poor Lazarus, who "neither accused God, nor reproached the Divine Providence" (PG 63, 637, 501). In this way the theme of the homilia (eumathia) is communicated to the audience-contempt for wealth-and their prosexis is ensured, when he reminds his listeners of the parable of the rich man and Lazarus and poses the question "How can the one that curses God, while not suffering from illness or any other calamity, can be forgiven, when his fellow humans that are suffering, like poor Lazarus, praise God?” (PG 63, 637, 502).

Following the principles of Omilitiki that require from the orator to converse directly with the audience, and the Rhetoric that makes it necessary for the listener to prepare for the transition from one section to another, Chrysostom moves to the main part of his homilia through a passins rhetorical question: "Why does wealth seem profound to you, people?” (PG 63, 637, 502). And the reasons, for which man hunts wealth, are: pleasure, flattery, fear and vengeance. So, not only it is not worthwhile for man to be chasing wealth, but he must also be very careful, not to be deceived by the wealth, like the men fooled by ugly whores, who seem prettier, with the use of cosmetics and make-up ${ }^{22}$. And if it sometime happens that the wealth is lost, then the masks are falling and happens exactly the same thing, as with the aforementioned women who use make-up the true face of those surrounding the formerly rich person is revealed. The people who surrounded and cajoled him earlier, feel hatred and loathing for him, now that he is poor.

So, wealth, according to Chrysostom, is one ungrateful slave, sadistic and slayer, ready to lead his master to slaughter, for the right amount of money. To reinforce the impact of his he reminds his audience of Eutropius, one of the richest and most powerful men of the empire, which was found to be "the most wretched of prisoners and the most miserable of suplicants" (PG 63, 638, 503), when he fell into disgrace with the Emperor Arkadius, with not even being able to be saved by his wealth. Chrysostom is particularly eloquent in the description of the weak and fearful Eutropius: "his face is pale, worse than that of a dead man his teeth are knocking, he is shaking, and words barely come out of his mouth”. And addressing Eutropius (in second person singular), in whose person he sees every believer, he will say: "If you weren't afraid of change, you haven’t experienced one” (PG 63, 639, 503).

After his reference to the example of Eutropius, Chrysostom will move to a new section of his homilia, having prepared his listeners accordingly: wealth betrays those who do not use it correctly "and it was high time that the truth of things came to light" (PG 63, 639, 504). Chrysostom is not keen to attack those who are rich, but those who are predators, not frightened the hatred these rich people hold against him, not even if they begin a war against him, because $\mathrm{He}$ is interested in a single thing the advancement of those who listen to his word. The threats against his life are nothing more than promises for wreaths and his wounds are his prizes/awards. By using the unbound format/syntax, the reset, the 'omiotelefton

\footnotetext{
${ }^{21}$. See Gospel of Luke, 16, 19-31.

22 . As was the case with St. Basil, John Chrysostom also uses paromoiosis greatly, especially the ones appearing in the form of a parabole- see footnote 10 .
}

schima' and alliteration, he emphasizes his determination to remain steadfast in what he believes in and sayins, "The determined one gets pelted, the determined one is hated, and the determined one is conspired against" (PG 63, 639, 504). For Chrysostom, the one and only right way to use wealth, is to give it away to the poor. People who do so are the only rich ones, full of love and good deeds.

At this point of his homilia, Chrysostom finds it appropriate to deal with the issue of equality between people: rich and poor are equal and are no different in anything $^{23}$. He thinks, therefore, that the rich are the ones that have the need of the poor; the poor do not need the rich. The example he uses, in order to prove his position, is also characteristic of his rhetoric skills: He makes up from scratch, like Plato, two cities; one only with rich people, and one only with poor. In the city of the rich there are no craftsmen, since no rich man condescends to practice manual labor; worthy of such professions are only the poor, according to the perceptions of that time. And a reasonable question arises: "'How will such a city operate (and survive)?” (PG 63, 641, 505). Instead, in the city of the poor, the living conditions are not difficult, because poor people are able to "work the iron" and "manufacture clothes” (PG 63, 641, 506), with no need for gold, silver and precious stones. Once again, the question comes naturally: "Where (in which case) are we going to ask the rich people for something ...” (PG 63, 641, 506) in this city?

Thus, believers must stop being jealous of the rich, imitating the Apostles, the Prophets and Christ Himself, "who did not have where to rest his head" 24 (PG 63, 641, 506). They must quickly recover from such (jealous) thoughts, recitinng the words of Christ: "it is not possible for a rich man to enter the Kingdom of Heaven ${ }^{25}$ ". Besides, if they lose the Kingdom of Heaven, even if they have conquered the whole world, their worth will be minimal, not even equal, as he characteristically claims, to three oboli. It is inconceivable, according to Chrysostom, for each of us to feel delighted, when invited to lunch by a king, but when it comes to stand beside the King of Heaven and enjoy eternal glory, to hesitate and stand with the mouth open, indecisive.

So he will exclaim: "What insensitivity!" He is unable to understand the behavior of people who prefer, falling into the trap of the devil, the small (trivial) from the large (important) things. His word becomes extremely strong, alive and poetic using the polysyndeton 'Smyth, 1984 - Lausberg, 1988. Efstathiou, 1994- Stergioulis, $2010{ }^{26}$, the "parison" or "isokolon schima" ${ }^{27}$, the "omiotelefton" 28 , the metaphora and the antithesis ${ }^{29}$. People have not realized that wealth is "a constant and unsaturated enemy” (PG 63, 642, 507), still tormenting people even after death. Even convicts receive better

\footnotetext{
${ }^{23}$. Before he proceeding in the justication his position, Chrysostom is critical of the irrational habit of the rich people to possess slaves.

${ }^{24}$. See Gospel of Matthew, 8, 20 and Gospel of Luke, 9, 58.

${ }^{25}$. See Gospel of Matthew, 19, 23.

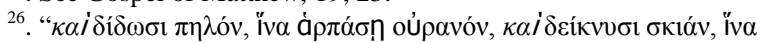

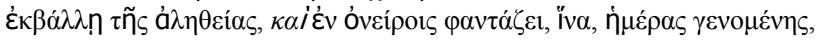

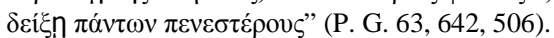

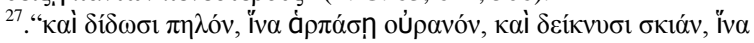

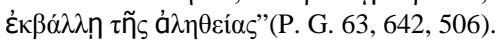

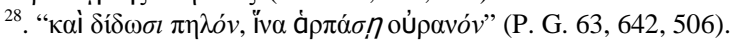

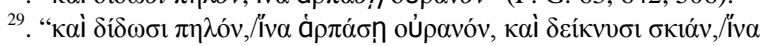

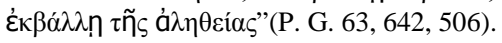


treatment after death, since after the first or second day of execution they are burried and rest in peace, while rich people, when they die, "are strip naked and reviled by grave robbers” (PG 63, 642, 507).

Therefore, wealth, according to Chrysostom, is not "a great good"· the greatest good is "the fear of God" (PG 63, $643,507)$. The fear of God gives more power to the righteous and poor man, for him to cope with the problems of life, compared to the rich - all he has to do is raise his hands to heaven, pray and the cloud "disappears" (PG 63, 643, 507). The example from the Bible is imperative to strengthen his argument: Apostle Peter was not rich, but with a simple word of his, "he resurrected the dead, cured the cripple and destroyed demons" (PG 63, 643, 507); he always admitted: "I possess neither gold, nor silver” (PG 63, 643, 507) ${ }^{30}$. And Apostle Paul, “walked and preached around the whole (known) world, hungry, thirsty and with no clothes" (PG 63, 643, 507). This section will end with the admonition of Chrysostom to his audience, not to abandon God for profit.

The last section of the main part of the homilia "About wealth and poverty" starts with a question:”Isn't just the zenith of foolishness, not knowing that you're winning?" (PG 63, 644, 509). There isn't a more brainless man, than the slave of money, since "he thinks he is powerful, (but) he is a prisoner he thinks he is a master, (but) he is a slave" ${ }^{31}$ (PG 63, 644, 509). He semms like the one who sees a menaced dog attacking him and, instead of tying him up, he gives him even more food, in order to attack him with even greater strength. Mental peace will only come when man stops the relentless hunt for wealth. The mental condition of the stingy rich man is vividly described by Chrysostom through a metaphor: as we call a prisoner lousy, because of the many shackles he is tied to, equally lousy is the rich man, due to his own shackles. In fact, the latter is worse than a prisoner, because his jailer is the wicked love for money that does not leave any margin of escape from his prison.

God gave riches, not to drive man to destruction, but to use them in works pleasing God and so be saved. That is why wealth is uncertain and impermanent; ie, to decrease the intense urge for earning money. Poorer yet richer man than the prophet Elijah did not exist. His indigence was legendary. He lived in a cave and had nothing valuable except his roan. Still, according to Chrysostom, the Prophet's roan was "brighter than purpura" (PG 63, 645, 510) and his cave was brighter than any royal palace. That's why that, when he departed in a fiery chariot for Heaven, he left his roan to his pupil Elisha, as a precious gift. The naturally arising conclusion, according to Chrysostom, is: "Indigence is a strong and invincible weapon” (PG 63, 645, 510).

Finally in the epilogue, (PG 63, 646, 510) of his Homilia, Chrysostom advises believers to deal, in the most Christian way, with the possible loss of their property. Having in mind the example of fair Job, they should exclaim: "The Lord gave it to us, the Lord shall take it from us" 32 (PG 63, 646, 510) and praise His name: "Blessed be the Lord, as we will come across something

\footnotetext{
${ }^{30}$. See Acts 3, 6.

${ }^{31}$. The use of figures of homilia and expressive means is quite

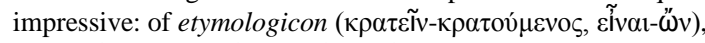
epanaphoras, parichisis and antithesis.

${ }^{32}$ See $J o b, 1,21$.
}

far more valuable than wealth" (PG 63, 646, 510). Such an attitude certainly ensures, for every believer, the "eternal life' (PG 63, 646, 510) ${ }^{33}$.

\section{Epilogue}

Both great Fathers suggest, as the only way to tackle lust for riches and avoid it, adopting an ascetic morality (Pelegrinis, 2009) according to the Christian model: selfcontrol and self-sufficiency in daily life. Besides, the moral problem of as ascetic is found in man's relationship with material goods, and not in their management, as rightly pointed out in the two inspirational speeches. This results in a new type of man, "a religious one, of deep spiritual quality", according to Tatakis, "a man, who is human as a whole. It is no longer about the citizen, neither the individual, nor just man" (Tatakis, 1977) and has nothing to do with a virtual man, as imagined by Socrates.

\section{References}

[1] Abrams, M. H. 2005. Literary terms vocabulary, translation by Gianna Delivoria-Sofia Chatziioannidou, Athens.

[2] Altaner, B.-Stuiber, A. 1978. Patrologie, Leben, Schriften und Lehre der Kirchenväter, Freiburg-Basel-Wien.

[3] Balanos, Dimitrios. 1951. Byzantine ecclesiastical writers from 800 to 1453, [Apostolic Ministry Library, no. 34], Athens, 298304 (Basil Caesareas) and 341-376 (John Chrysostom).

[4] Baur, Chr. 1929-1930. Der Heilige Johannes Chrysostomus und seine Zeit, vol. I-II, München.

[5] Bernardi, Jean. 1968. La Predication des peres cappadociens: le preidicateur et son auditoire, Presses universitaires de France.

[6] Bozinis, Konstantinos A. 2003. John Chrysostom on Imperium Romanum, A study on the politicl thinking of the Church, Athens: Published by the A. Kardamitsas Book Institute, pp. 241-257.

[7] Browning, R. 1966. Notes on Byzantine Prooimia, (Wiener Byzantinistische Studien no. 1: Supplementum), Wien.

[8] Burger, A. D. C. 1964. A Complete Bibliography of the Scholarship on the Life and Works of Saint John Chrysostom, Evaston.

[9] Christou, Pan. 1978. (St.) Basil the Great. Life and times, writings, theological thinking, [Vlatades Analects no. 27], Thessaloniki.

[10] Christou, Pan. 1989. Greek Patrology, [Christian Grammatology no. 2], Patriarchal Institute for Patristic Studies, Thessaloniki, vol. IV, 20-104 (Basil Caesareas) and 231-322 (John Crysostom).

[11] Courtonne, Yves. 1935. Saint Basile Homélies sur la richesse: édition critique et exégétique, Paris.

[12] Datema, C.-Allen, P. 1981. "Text and tradition of two Easter Homilies of Pseudo-Chrysostom”, Jahrbuch Österreichischen Byzantinistic No. 30, p. 87-102.

[13] Detorakis, Theocharis E. 1995. Byzantine Literature. Persons and texts, Heraklion of Crete, vol. I, 248-272 (Basil Caesareas) and 380-409 (John Crysostom).

[14] Efstathiou, Athanasios Agg. 1994. The Language of "Occasional Speeches” by Isidoros Glavas, archbishop of Thessaloniki (13801396), Typescript thesis, [Aristotle University of Thessaloniki, Faculty of Philosophy, Literature Department], Thessaloniki.

[15] Fedwick, P.G. 1981. Basil of Caesarea: Christian, Humanist, Ascetic, vol. I-III, Toronto.

[16] Festugiére, A. J. 1959. Antioche païenne et chrètienne (Libanius, Chrysostom et les moines de Syrie), Paris.

[17] Hartney, A. M. 2004. John Chrysostom and the Transformation of the City, Duckworth, London.

[18] Hunger, H. 1964. Prooimion. Elemente der byzantinischen Kaiseridee in der Arengen der Urkunden (Wiener Byzantinistische Studien no. 1), Wien.

\footnotetext{
${ }^{33}$. As is the case with St. Basil, John Chrysostom, also interested in ensuring the eternal life, embraces the eschatological perception of History.
} 
[19] Høgel, Christian (ed.). 2002 Symeon Metaphrastes Rewriting and Canonization, Museum Tusculanum Press, University of Copenhagen, pp. 142-145

[20] Illert, Martin. 2000. Johannes Chrysostomus und das antiochenisch-syrische Mönchtum, Studien zu Theologie, Rhetorik und Kirchenpolitic im antiochenischen Schrifttum des Johannes Chrysostomus, Zürich.

[21] Kelly, J. N. D. 1995. Golden Mouth. The Story of John Chrysostom-Ascetic, Preacher, Bishop, London.

[22] Kennedy, George. 1983. Greek Rhetoric under Christian Emperors, Princeton Univercity Press.

[23] Kennedy, George. 2000. History of Classic Rhetoric, Ancient Greek and Roman, translation by Nikos Nikoloudis, supervision by Ioannis Anastasiou, Athens, p. 420

[24] Koukoura, Dimitra. 2003. Rhetoric and Ecclesiastic Rhetoric, Timeless Study, Thessaloniki, p. 230.

[25] Lausberg, H. 1988. Handbook of Literary Rhetoric A Foundation for Literary Study, ed. David E. Orhon and R. Dean Anderson, Brill, Leiden, Boston-Köln, pp. 124-136.

[26] Lieberich, H. 1900. Studien zu den Proömien in der griechischen und byzantinischen Ge-schichtsschreibung, II. Teil: Die byzantinischen Geschichtsschreiber und Chronisten (Programm des Königlichen Realgymnasiums München 1899/1900), München.

[27] Mayer, W. John Chrysostom: Extraordinary preacher, ordinary audience: Preacher and Audience, Leiden-Boston-Köln, pp. 105137.

[28] Mazal, O. 1974. Die Prooimien der byzantinischen Patriarchenurkunden (Byzantina Vindobonensia no. 7), Wien.

[29] Meredith, A. S. J. 1998. The three Cappadocians on Beneficence: A key to their audiences: Preacher and Audience, Leiden-BostonKöln, pp. 93-99.

[30] Metallinos, G. D. 1968. Epitaphios in the Gregory the Theologian for (St.) Basil the Great, Introduction, Text, Translation, Comments, Athens.

[31] Moulard, Anatole. 1949. Saint Jean Chrysostome: sa vie, son oeuvre, Procure generale du clerge, Paris.

[32] Neill, S. 1962. Chrysostom and his Message: a selection from the sermons of St. John Chrysostom of Antioch and Constantinople, [World Christian Books 44], London: Lutterworth Press

[33] Papadopoulos, Stylianos. 1990. Patrology, Athens, vol. B', 355407.

[34] Papadopoulos, Stylianos. 1999. Saint John Chrysostom, vol. A'-B', Athens.

[35] Pelegrinis, Theodosis. 2009. Vocabulary of Philosophy, The Concepts, the theories, the Schools, the Trends and the Persons/ Six-Language Terminology, Athens.
[36] Pernot, Laurent. 2005. Rhetoric in Ancient Times, translation by X. Tselenti, edited by V. Sereti, Athens 2005 (Laurent Pernot, La rhétorique dans l’ antiquité, Librairie Générale Française, Paris 2000).

[37] Pratsch, Th. 2005. Der hagiographische Topos, Griechische Heiligenviten in mittelbyzantinischer Zeit, [Millenium Studies VI] Walter de Gruyter-Berlin-New York, 19-53.

[38] Quasten, Jon. 1975. Patrology, Utrecht-Antwerp, vol. III, 204-236 (Basil Caesareas) and 424-482 (John Chrysostom).

[39] Russel, D. A.-Wilson, N. G. 1981. (ed.) Menandros, "Peri epidiktikon", Menander Rhetor, edited with translation and commentary, Oxford at Clarendon Press.

[40] Sakellariadis, Georgios Ch. 2004. Modern vocabulary for linguistic terms and topics, Athens.

[41] Schatkin, M. A. 1987. John Chrysostom as Apologist, [Vlatades Analects no. 50], Thessaloniki.

[42] Smyth, H. 1984. Greek Grammar, Harvard Univercity Press, Cambridge, Massachusetts.

[43] Spengel, Leonardus. 1856. (ed.) Tryfon, Peri tropon, Rhetores Graeci, vol. III, Lipsiae.

[44] Stergioulis, Charalampos. 2009. Speeches in the translation of St. John Chrysostom's relics, Contribution in the study of funeral oration of the Byzantines, [Byzantine Research Center 52], Thessaloniki.

[45] Symposium. 1973. Studies on St. John Chrysostom, [Vlatades Analects No. 18], Thessaloniki.

[46] Tatakis, V. N. 1977. Byzantine Philosophy, [General Education Library 5], Modern Greek Culture and General Education Studies Company, Athens, p. 27

[47] Theodorakopoulos, Vas. 1989. Introduction to the Attic Oratory, The Birth of Oratory-The Ten Orators-The Rhetoric Art, Athens.

[48] Troiano, M. S. 2001. Il "Contra Eunomium III” di Basilio di Cesarea e le "Epistolae ad Serapionem I-IV" di Atanasio di Alessandria: nota comparative. Augustinianum vol. 41, 59-91.

[49] Venedictus, Hieromonk. 1998. Complete Works of (St.) Basil the Great, Mount Athos.

[50] Venedictus, Hieromonk. 2002. Complete Works of (St.) John Chrysostom, Mount Athos.

[51] Walter, Christopher. 1978. "Biographical Scenes of the three Hierarchs”', Revue des Études Byzantines, no. 36, pp. 232-234 and 250-259.

[52] Zisis,Theodoros. 2001. Comfort to the mourners: the comforting letters of (St.) Basil the Great, Thessaloniki. 